\title{
Corona Wedi Buto: Myth in the Efforts of the Tanggulwelahan Villager Facing Covid-19
}

DOI: https://doi.org/10.47175/rissj.v2i2.217

\section{| Ifan Andriado1, | Hamida Zama Rahmatillah² | | Anis Khoirun Nisa ${ }^{3}$ | Joan Hesti Gita Purwasih ${ }^{4, *}$ |}

\author{
${ }^{1}$ Senior High School 02 \\ Malang, Indonesia. \\ ${ }^{2,3,4}$ Deparment of Sociology, \\ Universitas Negeri Malang, \\ Indonesia
}

*Joan.hesti.fis@um.ac.id

\begin{abstract}
The COVID-19 virus was declared by WHO as a pandemic towards the beginning of 2020. As a result, Indonesia also implemented physical distancing nationally. This condition was responded to quite diverse by the community, one of which was in Tanggulwelahan Village, Tulungagung Regency. Myth is actually an alternative that people use in addressing these conditions. Therefore, researchers apply qualitative research methods (phenomenology) to explain the social construction of myths in the efforts of local communities to deal with COVID-19. Based on the results of interviews, observations, and analyzes using social construction theory the following results are obtained. "Buto" figure is a sacred symbol for the community because it is believed to have supernatural strength so that it can banish various outbreaks of disease. This understanding was formed through the process of externalization, objectification, and internalization that has been going on for generations. Meanwhile, medical information related to COVID-19 is new knowledge, so it is difficult to replace the old knowledge of society which is actually a myth.
\end{abstract}

KEYWORDS

COVID-19; myth; buto; social construction; village community.

\section{INTRODUCTION}

Recently, the world is stirred by the emergence of virus very worrying to everyone. The virus intended is corona virus. Indonesia experienced a major disaster caused by Covid-19 which was also experienced by other countries such as China (Berutu et al, 2021). Corona virus is a type of virus that can induce flu and severe diseases such as Middle East Respiratory Syndrome (MERS-CoV) and Severe Acute Respiratory Syndrome (SAR-CoV) (Mona, 2020). WHO (World Health Organization) stated that the world is experiencing emergency condition due to this new type of virus presence. The presence of COVID-19 (Corona Virus Diseases 2019) is very worrying and affects the world's community greatly. Even this virus transmission scale is considered as same as the World War II, in which large-scale international activities were postponed or cancelled entirely (Buana, 2020). The Covid-19 disease outbreak that originated in Wuhan China has spread very rapidly throughout the world (Fuady et al, 2021). The virus categorized into infectious disease becomes pandemic throughout world in early 2020. There is an assumption that corona virus appears and is transmitted from animal to human. However, as time goes by this virus is putatively transmitted as well by a human to another (Nurhalimah, 2020).

Considering this more widely transmitting virus pandemic beginning to enter into Indonesia, Government could not let it go silently. It has established disaster emergency status effective since February 29 to May 2020 or about 91 days. Government has taken 
many attempts to break the virus dissemination chain. The attempts taken are to socialize social distancing action, in which the government appeals the people to keep social distancing with others at least in 2 meter space, not to make direct contact with others, and to avoid massive meeting (Buana, 2020). In addition, government also appeals the people to keep cleanliness through washing hand and wearing mask outside home. The attempts the government has taken to minimize the dissemination of corona virus are getting stronger with the release of government's circulars, among others: 1) Minister of Education and Culture's Circular Number 3 of 2020, and Number 36962/MPK.A.HK/2020 about Online Learning and Work From Home (Ministry of Education and Culture, 2020;2) Ministry of Religion's Circular Number 8 of 2020 about the implementation of Ramadhan activities (Ministry of Religion, 2020;3) Minister of Finance's Circular Number SE7/MK.1/2020 about the Improvement of Alertness to the Prevention of COVID-19 dissemination (Kemenkeu [Ministry of Finance], 2020). Even Yunus \& Rezki (2020) stated that government has established special service accessible to the people concerning virus dissemination in Indonesia in order to avoid hoax that can trigger social panic.

People have responded positively to a variety of attempts taken by government to prevent corona virus dissemination. Such the response can be seen from people's compliance with the government's appeal despite adaptation needed in the beginning of appeal. Even, people have more varying ways to prevent this virus dissemination than those instructed by the government. Some people not only implement medical and governmental appeals but also take preventive measures by combining local wisdom. The local wisdom intended is tolak bala (disaster warding-off) media considered as capable of expelling any form of hazards, whether economic crisis or disease transmission. This local wisdom emerges hereditarily from one generation to the next, thereby creating a tradition.

The use of a media to prevent corona virus dissemination through combining tolak bala media as the form of local wisdom can be seen in Tanggulwelahan Villagers, Besuki Sub District, Tulungagung Regency. The media is manifested into a mask with Buto or Tetek Melek character image made deliberately using traditional medium (palm midrib or bongkok) and put in the front of house's entrance. Some Tanggulwelahan villagers believe that putting the terrifying character (Buto) can prevent any bad luck/disaster from entering into house. This news on tradition is still becoming hot topic in mass media, for example Lailil's (2020)'s essay entitled "Melihat Ritual Tetek Melek di Dusun Wajak, Desa Wajak Kidul (Seeing Tetek Melek Rite in Wajak Hamlet, Wajak Kidul Village”, and contained in radartulungagung.jawapos.com. In addition, another essay was written by Putra (2020) entitled "Tolak Corona, Warga Tulungagung Pasang Topeng Tetek Melek Tradisi Pengusir Wabah Penyakit (warding off Corona, Tulungagung People post Tetek Melek Mask, a tradition to expel disease epidemic)", contained in jatim.idntimes.com, and other mass media. The mass media explains how Javanese people, particularly those in Tulungagung Regency, still hold tightly on myth and tradition amid medical appeal in relation to corona virus dissemination. People feel that this virus dissemination is a pageblug (calamity) condition experienced by all villages, because this virus dissemination has affected social and economic condition of local people significantly. Pagebluk itself is defined as the period of time when people encounter life problem affecting all of their activities simultaneously. The placement of Buto/Tetek Melek character mask is believed to be able to safeguard the village from the negative effect of virus dissemination. Considering this phenomenon, some people utilize this chance to be economic income source. They sell any type of Buto/Telek Melek mask for the tradition purpose. The phenomenon is also addressed by Perdana (2020) stating that some people deliberately 
create a variety of Buto/Tetek Melek to be traded in order to fulfill the need for tradition undertaken by the people surrounding Tulungagung Regency.

Some previous studies have been conducted, but not explain the contra construction between cultural and medical knowledge. there are isolation soncept in social network (Mona, 2020), the improvement of knowledge in dealing COVID-19) (Sulaeman \& Supriadi, 2020), Puskesmas as government's right hand in dealing COVID-19 (Utami, 2020), state defending attempt through social distancing and lockdown (Nurhalimah, 2020), and analysis behavior and the trick to maintain mental health (Buana, 2020). The five previous studies tend to see the phenomenon of corona virus contagion viewed from medical and governmental attempt of minimizing the virus contagion. It indicates that no study investigates specifically the local people's attempt of preventing corona virus transmission using the local perspective. Therefore, this research has novelty that can fill in the literacy gap and try to describe community behavior from their local perspective. 'Tolak bala' as the myth and local knowledge still maintained well until today. Therefore, this research showed that the local knowledge alwas be reproduce although in difference condition like in the pandemic COVID-19.

The urgency of current research lies on the people remaining to maintain the local wisdom tradition (placement of Buto/Tetek Melek mask) amid intense medical and governmental appeals to prevent corona virus contagion. It does not mean that the people ignore governmental appeal, but they keep using the media as the complementary one believed to help minimize virus contagion based on Javanese tradition and myth. It of course makes the author interested in conducted further study entitled "CORONA WEDI BUTO: Myth in the Efforts of the Tanggulwelahan Villager Facing COVID-19 (Corona Virus Disease 2019)". This research aims to describe the myth in Tanggulwelahan villagers' effort of facing COVID-19 (Corona Virus Disease 2019).

\section{RESEARCH METHODS}

This research employed a qualitative method witth phenomenology approach. Phenomenology focuses on the commonality of a lived experience within a particular group. The fundamental goal of this approach is arrived description of the common particular phenomenon (Creswell, 2007). Phenomenology used for constructing the local community common experience about universal understanding of Buto. Techniques of collecting data used were observation, in depth interview, and documentation. The purposive sample used for considered the informants. They are key informants with capable of explaining local wisdom of Buto/Tetek Melek mask placement. The informants were: Mr. Dasar, Mr. Parel, Mr. Kusnan, Mr. Sukadi, and Mrs. Yamah. They also used the Buto Mask in the house for facing COVID 19. Triangulation in this qualitative research used to test validity through the convergence of information from different sources (Neuman, 2011). Technique of analyzing data used was Miles and Huberman's interactive one, consisting of data collection, data reduction, data display, and conclusion drawing.

\section{RESULTS AND DISCUSSION}

\section{Myth in Tanggulwelahan Villagers' Effort of Facing COVID-19 (Corona Virus Disease 2019)}

Local wisdom is the community's product created through a very long process. This process in turn makes local wisdom standing as the people's philosophical reference and life guidance. Considering local wisdom as the product of community, it can be seen that local wisdom is always dynamic in nature just like the community culture. Local wisdom 
should be viewed as the product of lofty value present hereditarily. Therefore, to see local wisdom, it is unnecessary to be associated with right or wrong perspective, the more important point is to see the goodness of local wisdom (not the truth but what's the good). Local wisdom is a product of society's cultural system, while cultural system consists of value and norm strengthened with community habitus in the form of tradition and custom. For that reason, the custom existing within society is due to the presence of strong cultural value system within the society.

Cultural value system is the highest and most abstract level of custom. It is because cultural value system is composed of some concept on anything existing in the people's mind they consider as very valuable, precious, and important, thereby can function as a guideline giving life direction and orientation in the future (Koentjaraningrat, 2009). Although Koentjaraningrat explains that cultural value can be used as the people's life guideline, as a concept the cultural value has very common characteristics and broad scope, and is difficult to be explained rationally and really. It is because cultural value has been cultural values have penetrated into the people since they were so young that entrenching into the people's life. Cultural values have entrenched and fused into selfemotion, nature, and soul of the people with corresponding culture. That is why cultural value is almost irreplaceable with other cultural values in short time, by means of discussing it rationally.

Each member of community is, either complexly or simply, composed of a number of cultural values interrelated thereby creating a system. This system is used the guideline of ideal concept of community construction successfully motivating and directing the people's life (Koentjaraningrat, 2009). A strong example of society's cultural system is Javanese society's cultural system. Javanese people still hold tightly on their culture, particularly belief value replete with mythologization (mythologyzing), sacralization (seeing anything as sacred), and mystification (seeing anything as a mystery). Anything is mythology that can be found in people, place, time, and event. Myth is important in Javanese people's life as it contains not only the interpretation on world and entire content, but also sample model of its existence in the world. Thus, according to Javanese community, myth is neither the product of intellectual thinking nor the product of logic construction, but spiritual and mental orientation related to God. The reality of Javanese myth can be seen in many forms, one of which is tradition.

One of traditions attracting people and mass media's attention recently is the one in Tanggulwelahan Village, Besuki Sub District, Tulungagung Regency. In this case, people try to combine governmental appeal and local belief or tradition in preventing corona virus contagion. Basically, Tulungagung people are those holding tightly on Javanese tradition. It can be seen from the event of posting Buto/Tetek Melek amid government's intense socialization about the attempt of preventing corona virus contagion. Positive response is manifested into social activity prioritizing health protocol including social distancing, wearing mask, avoiding massive assembly, and always washing hand. However, not only they undertake governmental appeal in dealing with this corona virus contagion but they also uphold Javanese tradition believed to be an alternative measure to prevent virus transmission. People believe that the placement of Buto/Tetek Melek mask can avoid people from any hazard to life in the future.

This community tradition has been raised to be the topic of discussion in online mass media, for instance, article written by Putra (2020) entitled "Tolak Corona, Warga Tulungagung Pasang Topeng Tetek Melek Tradisi Pengusir Wabah Penyakit (Warding off Corona, Tulung Agung citizens post Tetek Melek Mask as a tradition to expel disease epidemic)", contained in (https://jatim.idntimes.com/news/jatim/bramanta-putra/tolak- 
corona-warga-tulungagung-pasang-topeng-tetek-melek/full). This article suggests that the tradition of posting Buto/Tetek Melek mask has been conducted by local people for a long time since their ancient time. This tradition is sent down from one generation to the next. Considering the result of data exploration, the author can reveal successfully that the tradition inheriting process is conducted without compulsion. People stated that the posting process builds on the previous family's belief. People, whose parents apply this tradition in the past, tend to continue it by doing similar tradition during difficult lime time. It is confirmed by two informants, stating as follows:

"It only imitates our parents in the past. They always posted this mask when they face life problem. It is intended only to remove the life problem encountered so far." (Mr. Dasar, April 2020)

"This tradition has been existing since a long time ago, bequeathed hereditarily from our ancestors. The people here indeed still hold tightly on Javanese belief. However, not all people here post Tetek Melek mask. Only most of them use it. They usually do it because their parents did so in the past. It is how Javanese people pray to God to be kept away from any life hazard and to live peacefully (Mr. Parel, April 2020)

Considering the information obtained from some informant, it can be seen that the placement of Buto/Tetek Melek mask has been done since ancestor time. This tradition has been inherent to some of Tanggulwelahan villagers, in Besuki sub district, Tulungagung Regency. People assume that the corona virus contagion has created a variety of very complex life problems, whether in health, economic, or social aspect. Therefore, considering the negative effect resulting from this virus contagion, people call it pageblug. Pageblug (calamity) time is the time when people encounter life problem simultaneously affecting all of their activities. Moreover, the problem relates to human health and life. Most of them cannot rely on governmental appeal only through health protocol. Therefore, while undertaking the governmental appeal, majority of them also rely on Javanese belief by posting Buto/Tetek Melek as a medium to ward off this pageblug time. They intentionally paint the mask with Buto character. They choose Buto character because this character is expected to give evil image and character believed to ward off and frighten any hazard, including corona virus contagion. They also deliberately post the mask in front of house, door, terrace pillar, or entrance gate. The placement of tolak bala mask in front of house is expected to hinder any hazard harming the life from entering into home.

"That Javanese tradition does not appear suddenly. Javanese people are well-known for their Ilmu Titen (instinct). This tradition appeared because there was a similar problem in the past. Seeing that problem, Javanese people believe in one of way to solve it. If it is successful, Javanese people will believe that the way can solve the problem and tend to use the similar way when the similar problem come later. For that reason, this tradition of posting mask does not appear suddenly. It has been used by their parents since a long time ago because it is considered as capable of resolving pageblug period. Pageblug period is the time when everyone encounter the same problem. For example, a pest disaster has ever occurred in the past, people in one village could not harvest their plant due to the pest. It is called pageblug. Currently, it is not pest attacking the rice plant, but virus attacking people throughout world. Therefore, this mask is posted" (Mr. Kusnan, April 2020)

The process of producing and posting Buto/Tetek Melek mask is very simple. Tanggulwelahan villagers usually use bongkok (palm midrib) as the material for preparing the mask. Bongkok is the medium most easily found by local people. It is because they usually use Bongkok as fuel wood. Indeed there is no standard rule related to the use of 
palm midrib medium. This medium is used because of the easiness to get it. However, some people use other media such as log that have been chiseled resembling face mask. In addition, there is an easy way of preparing Buto/Tetek Melek mask. The first one is to prepare tools and materials needed. The tools needed are brush, saw, and nail/wire. Meanwhile, the materials needed are palm midrib/wood, and paint. The preparation procedure is very easy: firstly, make sure that the palm midrib or wood has been actually dry. It is intended to make the paint adhering easily to the surface of palm midrib during painting later. Then, clean the midrib and cut the unnecessary part using saw. If it has been neat, it can be painted with Buto/Tetek Melek character with paint and brush prepared. People usually paint it with terrible and evil character. It is believed that Buto's terrible face can frighten any hazard to come. After the face character has been painted, dry the paint under the sun in order to make it durable under rain. Then, after the paint has been dry, people can post it using wire or nail in front of house (in front of door or fence). Some people also adorn it with other additional equipments such as artificial hair to give Buto character image. To save the expense, they usually substitute the paint material with charcoal or chalk that can essentially be used to draw Buto face character.

"Preparing it is very easy. Its tool and material can be found easily as well, for example, palm midrib or wood, paint, brush, saw, nail or wire. No standard rule is available to prepare the Tetek Melek mask. It uses palm midrib because the medium can be found easily, and people use palm midrib as fuel wood. If there is no palm midrib, it can be replaced with wood. Firstly, the palm midrib should be dried, and then can be painted using paint or charcoal and chalk. Terrible and frightening face is drawn to frighten the hazard. Thereafter, it is sunbathed until dry, and then posted in front of house, entrance, or door (Mr. Sukadi, April 2020)

In addition to the meaning of Buto/Tetek Melek mask posting tradition, the most important point is that people still prioritize governmental appeal corresponding to the health protocol (corona virus transmission prevention). They still consider the health protocol as the main guideline in doing activities in addition to the implementation of Buto/Tetek Melek mask posting tradition as the medium to ward off the virus (tolak bala). People always do social distancing activity, just like the governmental appeal socialized. The documentation of Buto/Tetek Melek mask posting successfully collected by the author is presented below.

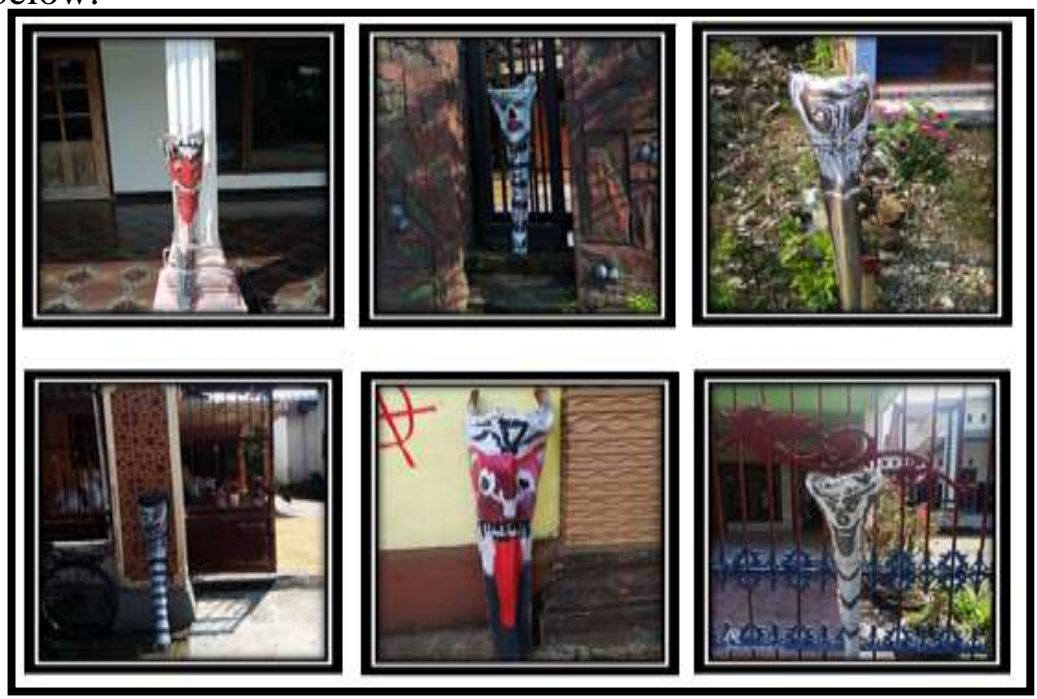

Figure 1. Buto/Tetek Melek Mask Posting in front of Tanggulwelahan Villagers' Houses, Besuki Sub District, Tulungagung Regency (Source: Processed by Author, 2020) 


\section{Myth in Tanggulwelahan Villagers' Effort of Facing COVID-19 (Corona Virus Disease 2019) using Social Construction Perspective}

Berger is one of very productive sociologists. He has very influential works in the social science development. His work entitled "The Social Construction of Reality" has contributed considerably to interpretative sociological realm. In addition, his work entitled "Invitation of Sociology" also contributes considerably and affects broadly as the introduction to sociology for social science academicians. The contribution can be seen from his works addressing social theory, religion sociology, knowledge sociology, study on modernization and social change trying to combine theological issue and practical politic (Dharma, 2018). Berger became a sociological and theological Professor in Boston University in 1981, and then was recruited by Institute on Culture, Religion, and World Affairs in 1985. Because of Berger's European language mastery, particularly German, he had broad access to early sociological sources in Europe, particularly Max Weber's and Emile Durkheim's works. Social construction theory was born due to, among others, a question posed to Berger about what the reality is actually. The question is affected by two philosophical perspectives: empiricism and rationalism. From the conception of knowledge sociology, Berger eventually can develop a concept formula concerning the presence of objective reality and the presence of subjective reality.

Berger assumes that human being is in objective and subjective reality world. In objective reality, human being is structurally affected by environment where he lives and stays (Light, Berger, \& Luckmann, 1967). From this, it can be explained that the direction of human development is determined socially, since they were born until they are adult, and old. There is a reciprocal relationship between social context and human self creating identity so that habituation process occurs inside human being. Meanwhile, subjective reality is that human being is considered as an organism with certain predisposition in living within society. It means that there is human subjectivity amid his social environment. Individual has taken over social world and shaped it according to the creativity he has. Originally, Berger's view focused on dialog on religiosity or religion sociology, but then it shifted to anything related to everyday life. Through phenomenological approach, Berger tries to emphasize the importance of human's religious experience that can be institutionalized into many traditions attempting to bind knowledge and behavior within society (Dharma, 2018: 2).

In analyzing social construction, Berger creates a Social Dialectic theory, in which he believes that the reality existing within society, either objective or subjective, is created through three dialectical moments: externalization, objectification, and internalization. Those moments do not always occur successively, but the creation of community is inseparable from those three moments, so that the analysis of community should be based on those three moments. Furthermore, the three moments can be explained as follows:

\section{Externalization}

In Externalization, Berger stated that the social space order is the product of human creation occurring contingently. The social order will always be produced by human beings through externalization process occurring continuously (Light et al., 1967). Berger said that externalization is the imperative form of anthropology. Therefore, the existence of human beings should keep externalizing themselves in the form of activities. Human beings will keep attempting to establish stable relationship with social environment (Dharma, 2018). So, briefly, externalization is the form of human's self action realized continuously into the world, either physically or non-physically (mentally). Such 
externalization can be understood as an individual's impulse to build his own world (Asilha, 2019).

In this research context, externalization is manifested into the placement of Buto/Tetek Melek mask as the tolak bala media amid corona virus contagion. The action of posting Buto/Tetek Melek mask is an action undertaken continuously over generations. This action has been the Tanggulwelahan people's habit, particularly when dealing with pageblug time perceived as harmful. Habituation aforementioned, in turn, will be Tanggulwelahan people's action pattern. Surely, the action that has been a habit has valuable meaning to individual or community doing it. The result of current research show that the meaning of Buto/Tetek Melek mask posting to Tanggulwelahan villagers is a tolak bala media they got hereditarily. They said that such tradition does not appear suddenly but there was a valuable moment occurring in the past leading their ancestor to take an attempt of dealing with the moment. The moment intended was the time when a village has experienced a trouble such as harvest failure due to pest. Thus, their ancestor decided to prepare tolak bala media believed to be able to expel any bad luck encountered by the villagers. Finally, the tolak bala tradition is still implemented until today, moreover in dealing with big problem such as corona virus contagion. So, it can be concluded that externalization process is manifested into physical attitude, the Buto/Tetek Melek mask posting and nonphysical (mental) attitude, the belief that Buto/Tetek Melek mask tradition can expel any bad luck and hazard encountered by local people.

\section{Objectification}

Human objectification process has been begun since human interacts with his environment. Daily experience will lead each individual and express it in the form of typical behavior pattern when interacting with other individuals. Externalization and objectification is a moment occurring in a dialectic process occurring continuously. Thus, community is a human product, or in other words, human is social producer and consumer all at once. The product is related to norms, morals, values, believes, myths, and etc. Social institution becomes the bridge of objectification in order to be understood as reality by its members (Rose, Berger, \& Luckmann, 1967). In addition, Berger also said that daily life action pattern has space and time structure. Time structure requires an individual to adjust his action with the constructed societal norms. It indicates the presence of hierarchic action in social order making an individual bond to the social role he plays. Meanwhile, spatial structure will restrict an individual in determining action or interacting with others (Dharma, 2018). So, essentially objectification appears when Buto/Tetek Melek mask posting tradition is conducted massively by Tanggulwelahan villagers. In this presence of tradition, people are indirectly required to do so because there is a Javanese binding assumption or belief. The tolak-bala media related belief is believed to be able to remove any bad luck and hazard from the village that has affected the local people's thinking. Thus, an assumption of "an imperative to hold tradition" keeps existing in their activity pattern and is binding in nature, particularly in facing the corona virus contagion. As long as the people believe that tradition should be implemented because of the belief in valuable meaning, at that time subjectification moment occurs as well within the society.

\section{Internalization}

Internalization is an important moment making an individual a part of society. To achieve internalization, an individual will experience the socialization process first. Socialization is divided into two: primary and secondary. Primary socialization is the first one obtained by 
individual. This socialization comes from family scope. Family plays an important role in creating its members' behavioral pattern. Meanwhile, secondary socialization is the followup process of primary socialization. This socialization is acquired from friend or environment where the individual lives (Dharma, 2018). So, it can be said that internalization is the process of reabsorbing the product of objectification into individual's subjective consciousness affected by social structure and social world. The form of internalization can be art, education, story, value, norm, belief, and myth sent down from on generation to the next.

In this context of research, the Buto/Telek Melek posting tradition is the product of objectification internalized hereditarily. It can be seen from Tanggulwelahan villagers' explanation that such tradition has been existing since their ancestor time. They also said that this tradition is bequeathed from one generation to the next, through either parents or surrounding environment. Event they argued that those holding Buto/Telek Melek mask posting tradition today tend to have parents holding the similar tradition in the past. It is this that makes them hold the tradition just like their parents in the past. This process proves that internalization process has been conducted successfully and inculcated strongly into the next generations.

\section{Research Framework}

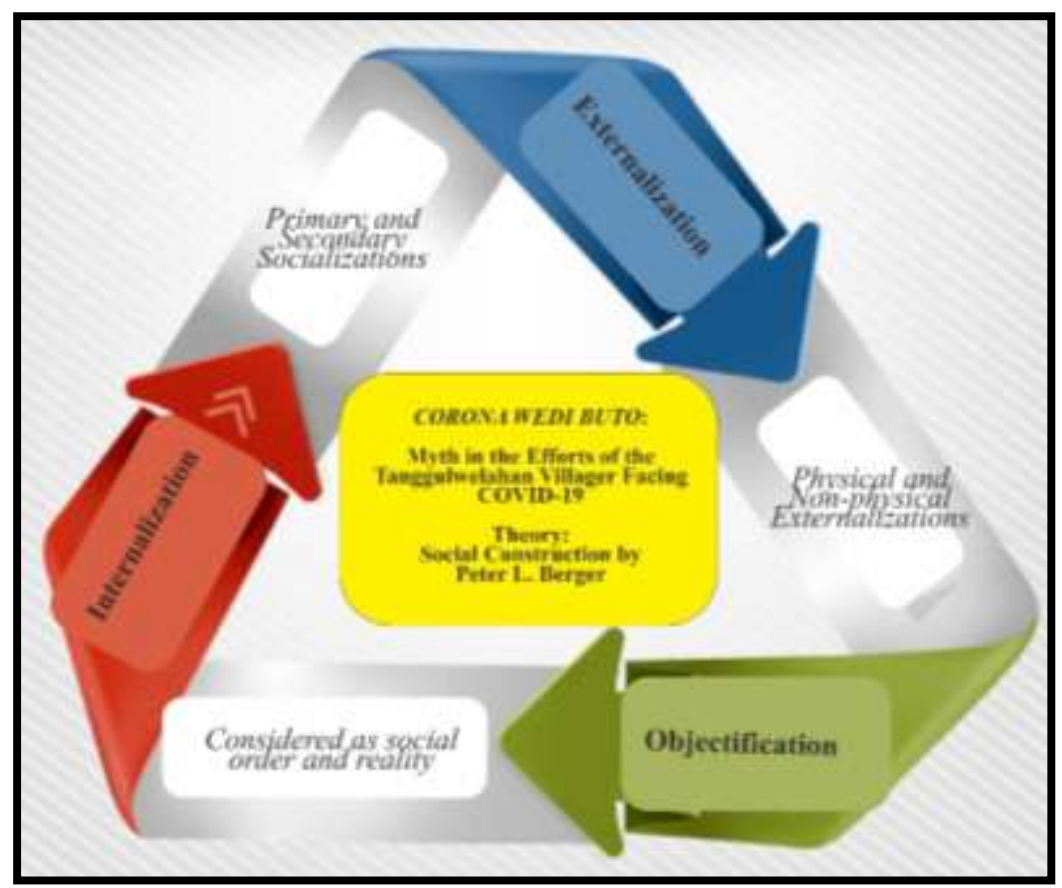

Figure 2. Research Framework (Source: Processed by Author, 2020)

\section{CONCLUSION}

The use of words "CORONA WEDI BUTO" represents the result of research the author has conducted. It builds on Tanggulwelahan villagers' tradition, in Besuki Sub District, Tulungagung Regency, i.e. the Buto/Tetek Melek mask posting as local wisdom in dealing with corona virus contagion. People assume that the corona virus transmission has results in a variety of very complex life problems, whether in health, economic, or social aspect. Therefore, considering the negative effect resulting from this virus contagion, people call it 
pageblug. Pageblug (calamity) time is the time when people encounter life problem simultaneously affecting all of their activities. Moreover, the problem relates to human health and life. Most of them cannot rely on governmental appeal only through health protocol. Therefore, while undertaking the governmental appeal, majority of them also rely on Javanese belief by posting Buto/Tetek Melek as a medium to ward off this pageblug time. They intentionally paint the mask with Buto character. They choose Buto character because this character is expected to give evil image and character believed to ward off and frighten any hazard, including corona virus contagion. They also deliberately post the mask in front of house, door, terrace pillar, or entrance gate. The author successfully presents this tradition-related study through theoretical study using Peter L. Berger's Social Dialectic theory. Considering the result of theoretical analysis, the tradition activity conducted by Tanggulwelahan Villagers is the product of people themselves, created through externalization, objectification, and internalization processes.

\section{ACKNOWLEDGMENTS}

The authors would like thanks to Social Science Faculty, Universitas Negeri Malang.

\section{REFERENCES}

Asilha. (2019). Teori Dialektika Sosial Menurut Peter L Berger Serta Relevansinya Dalam Studi Hadis.

Berutu, N., Hodriani, H., \& Budiwiwaramulja, D. (2021). Putri Renjani Manisan Product Standardization: The Efforts to Increase Product Sales in Pandemic Situations. Randwick International of Social Science Journal,2(1), 81-89. https://doi.org/10.47175/rissj.v2i1.181

Buana, D. R. (2020). Analisis Perilaku Masyarakat Indonesia dalam Menghadapi PandemiVirus Corona (Covid-19) dan Kiat Menjaga Kesejahteraan Jiwa? Journal Sosial Dan Budaya Syar'i, 7, 217-226.

https://doi.org/10.1017/CBO9781107415324.004.

Creswell, J. W. (2007). Qualitative inquiry and research design: Choosing among fivetraditions. Sage Publication. https://doi.org/10.1111/1467-9299.00177.

Dharma, F. A. (2018). Konstruksi Realitas Sosial : Pemikiran Peter L . Berger Tentang Kenyataan Sosial. Kanal: Jurnal Ilmu Komunikasi, 7(1), 1-9. https://doi.org/10.21070/kanal.v.

Fuady, I., Sutarjo, M. A. S., \& Ernawati, E. (2021). Analysis of Students' Perceptions of Online Learning Media During the Covid-19 Pandemic (Study of E-learning Media: Zoom, Google Meet, Google Classroom, and LMS). Randwick International of Social Science Journal, 2(1), 51-56. https://doi.org/10.47175/rissj.v2i1.177

Kemenkeu. (2020). Surat Edaran Nomor Se-7/Mk.1/2020 Tentang Upaya Peningkatan Kewaspadaan Atas Pencegahan Penyebaran Corona Virus Disease 2019 (Covid-19) di Lingkungan Kementerian Keuangan.

Koentjaraningrat. (2009). Pengantar Ilmu Antropologi Edisi Revisi 2009 (2009th ed.). Jakarta: PT. Rinneka Cipta.

Lailil, S. N. (2020). Melihat Ritual Thethek Melek di Dusun Wajak, Desa Wajak Kidul.

Light, D. W., Berger, P. L., \& Luckmann, T. (1967). The Social Construction of Reality: A Treatise in the Sociology of Knowledge. Sociological Analysis. https://doi.org/10.2307/3710424. 
Mona, N. (2020). Konsep Isolasi Dalam Jaringan Sosial Untuk Meminimalisasi EfekContagious ( Kasus Penyebaran Virus Corona Di Indonesia). Jurnal Sosial Humaniora Terapan, 2(2), 117-125.

Neuman, W. L. (2011). Social Research Methods: Qualitative and Quantitative Approaches. Pearson Education.

Nurhalimah, N. (2020). Upaya Bela Negara Melalui Sosial Distancingdan Lockdown Untuk Mengatasi Wabah Covid-19 (Efforts to Defend the Country Through Social Distancing and Lockdown to Overcome the COVID-19 plague). SSRN Electronic Journal. https://doi.org/10.2139/ssrn.3576405

Perdana, D. R. (2020). Buat Thethek Melek, Warga Desa/Kecamatan Campurdarat, Tangguk Rezeki di Tengah Korona Beromzet Jutaan, Sempat Dicemooh Orang.

Putra, B. (2020). Tolak Corona, Warga Tulungagung Pasang Topeng Tetek Melek.

Rose, D. M., Berger, P. L., \& Luckmann, T. (1967). The Social Construction of Reality. The Modern Language Journal. https://doi.org/10.2307/323448.

Sulaeman, \& Supriadi. (2020). Peningkatan Pengetahuan Masyarakat Desa Jelantik DalamMenghadapi Pandemi Corona Virus Diseases-19 (Covid-19) Sulaeman1, 1, 12-17

Utami. (2020). Puskesmas Sebagai Tangan Kanan Pemerintah Provinsi NTB Dalam Penanganan COVID-19. Puskesmas Sebagai Tangan Kanan Pemerintah ProvinsiNTB Dalam Penanganan COVID-19. https://doi.org/10.1017/CBO9781107415324.004.

Yunus, N. R., \& Rezki, A. (2020). Kebijakan Pemberlakuan Lock Down Sebagai Antisipasi Penyebaran Corona Virus Covid-19. SALAM: Jurnal Sosial Dan Budaya Syar-I,7(3), 227-238. https://doi.org/10.15408/sjsbs.v7i3.15083. 